\title{
THE ROLE OF SMALL TOWNS IN A POTENTIAL ECOREGION THROUGH THE EXAMPLE OF FERTŐ/NEUSIEDLERSEE CULTURAL LANDSCAPE
}

\author{
Ágnes Sallay, Zsuzsanna Mikházi, Klaudia Máté, Edina Dancsokné Fóris, \\ Krisztina Filepné Kovács, István Valánszki, László Kollányi ${ }^{1}$
}

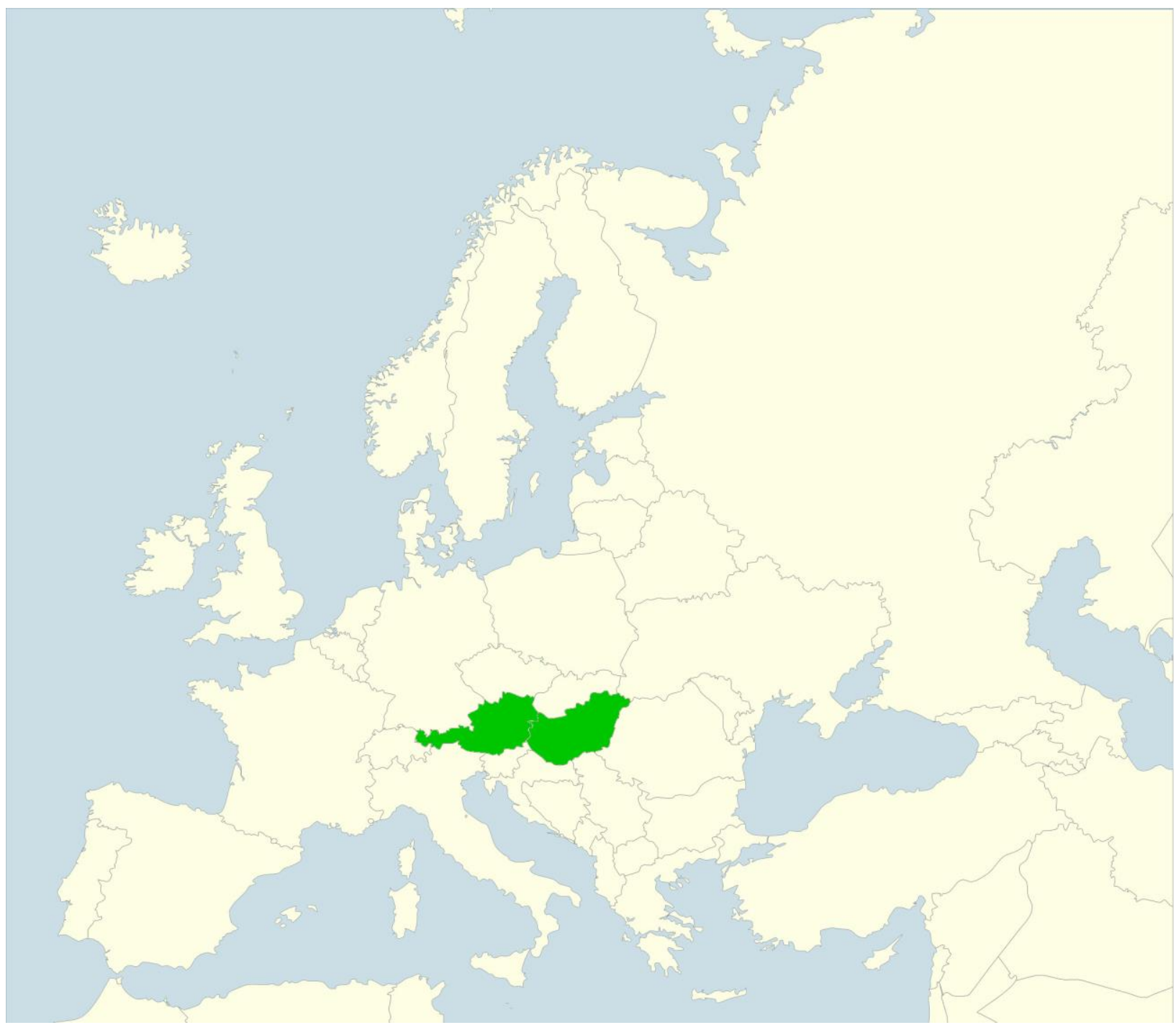

\footnotetext{
1 Ágnes Sallay, dr. habil, PhD, sallay.agnes@tajk.szie.hu, Zsuzsanna Mikházi, zsuzsanna.mikhazi@gmail.com, Klaudia Máté, mate.klaudia@phd.uni-szie.hu; Edina Dancsokné Fóris, dforisedina@gmail.com; Krisztina Filepné Kovács, dr., PhD, filepne.kovacs.krisztina@tajk.szie.hu; István Valánszki, dr., PhD, valanszki.istvan@tajk.szie.hu; László Kollányi, dr., CSc, kollanyi.laszlo@tajk.szie.hu; Szent István University, Department of Landscape Planning and Regional Development, Hungary, 1118 Budapest, Villányi út 35-43. K. II.
} 


\begin{abstract}
Fertö/Neusiedlersee Cultural Landscape, as a transboundary World Heritage Site of Hungary and Austria, possesses unique cultural and natural values. The examined areas can be characterised as meeting places of different cultures. We examined the role of small towns in Fertö/Neusiedlersee Cultural Landscape, which play an important role in regional development. In the last 25 years, different levels of cooperation started among the Hungarian and Austrian settlements aiming at nature and cultural heritage protection and tourism development. We formulated suggestions to maintain and strengthen the existing co-operation and relations.
\end{abstract}

Keywords: small towns, ecoregion, Fertö/Neusiedlersee Cultural Landscape, cultural landscape, cross-border tourism, world heritage

\begin{abstract}
Absztrakt: A Fertő-tó térsége speciális helyzetben lévő része Magyarországnak és Ausztriának egyaránt, melyet az I. világháború utáni határrendezés, majd a II. világháború után, közel 50 évre a „vasfüggöny” szakított ketté. 2001-ben a világörökségi terület cím elnyerése új lehetőségeket teremtett arra, hogy a települések visszaépítsék korábbi kapcsolataikat és az új fejlesztési irányt közösen dolgozzák ki. A Fertő/Neusiedlersee kultúrtáj szép példája a települések együttmüködésének, ahol a kisvárosok kiemelt szerephez juthatnak úgy, hogy a környező falvaktól nem vonják el az erőforrásokat. A kisvárosoknak nem csak a természeti és kulturális értékek megőrzésében és bemutatásában, de a fenntarthatóság biztosítására a térség ökorégióvá történö fejlődésében is fontos szerepük lehetne.
\end{abstract}

\title{
1. Introduction
}

We got to learn about Fertö/Neusiedlersee Cultural Landscape World Heritage Site more thoroughly when we were preparing the World Heritage Management Plan for the Hungarian side in 2015. We started to research the special situation of the local settlements, and their role in the subregion. The region of Lake Ferto is a special part of both Hungary and Austria. The area had organically developed as a whole for centuries during the era of the Kingdom of Hungary, although its territories belonged to numerous landlords. Thus the settlements developed in different ways. However, the settlements still formed a common base, in which they all had their distinct roles. A serious break in this relatively continuous development was the post-World War I period, which split the region in half by a newly formed state border. The border cut the once very active transportation and trade ties, and separated the city of Sopron from the settlements and markets in its agglomeration. Despite the separation, the settlements retained their roles, as the two countries had developed similarly after the recovery of the World War I damages. A complete split came with the period after World War II, as - with a few smaller exceptions - the significant industrial developments had avoided the region due to the construction of the Iron Curtain, which turned the area into a border region, and the settlements lost their living connections they had had before. The end of communism in Hungary in 1989, the recognition and gradual preservation of natural and cultural values, and the inscription of the area on the World Heritage List provided new opportunities in the region for the settlements to rebuild their once existing connections, and jointly define a new direction of development due to the attention received by World Heritage Sites. In our researches, we have looked at the role changes of the settlements, and the opportunities and dangers in the new direction of development.

Lake Fertő is a transboundary World Heritage Site of Hungary and Austria. The region has unique characteristics regarding both cultural history and nature conservation (Figure 1). There are numerous historic small towns around the lake, maintaining a rich cultural heritage, their roles however have changed many times in the previous century. Some settlements have achieved a town status due to the development of tourism, but many others have lost their central role because of the changes of the state border and the following migration. The likewise 
rich natural environment, together with the increasing importance of nature conservation, also affected the transformations of the settlement roles. Lake Ferto biosphere reserve received a certificate from UNESCO's Man and the Biosphere (MAB) programme in 1979. (The Austrian side of the lake received it in 1977.) Lake Ferto Landscape Protection Area was established in 1977 in Hungary, two years before the MAB certification. In 1983, the area has was also included on the "Ramsar List" (the List of Wetlands of International Importance). On the Hungarian side, Fertö-Hanság National Park was formed in 1991, followed by Neusiedlersee-Seewinkel National Park on the Austrian side two years later. The region is listed as a UNESCO World Heritage Site since 2001. In its decision 25COM X.A, the UNESCO World Heritage Committee listed the region with the number 772rev, with the title "Cultural Landscape of Fertö/Neusiedlersee". (Later, in 2003, the 27COM 8C.2 decision changed the title to "Fertö/Neusiedlersee Cultural Landscape".)

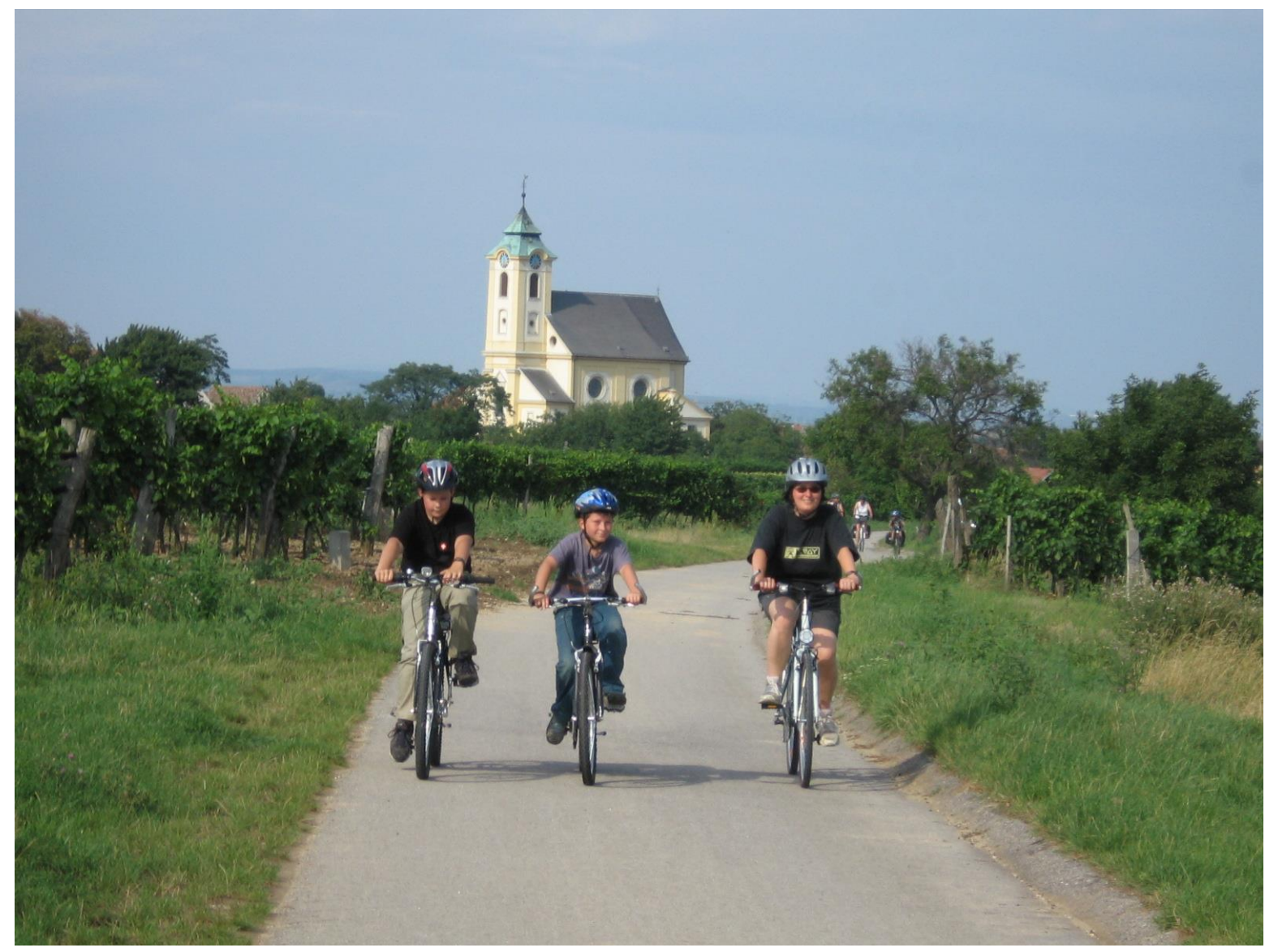

Fig 1. The region of Fertő is a popular tourism destination (Photo by T. Dancsók).

After Hungary joined the European Union in 2004, a significant part of the World Heritage Site also became a Natura 2000 area. The 2006 adoption of the National Land Use Plan introduced a further means of protection, which defined the area as part of the ecological network and landscape scenery protection. Five settlements in the Austrian side belong to Welterbe Naturpark as well. In the Lake Fertö region, the "disappearance" of the borders, and the designation of a common World Heritage Site brought new opportunities in restoring the once existing but artificially terminated cooperation. See Table 1 for the main characteristics of the examined area. 
Tab 1. Main characteristics of the region.

\begin{tabular}{|l|l|}
\hline & Fertö/Neusiedlersee Cultural landscape (Hungary-Austria) \\
\hline Outstanding values: & $\begin{array}{l}\text { A man ruled landscape of outstanding richness in species of } \\
\text { flora and fauna, gene-bank. } \\
\text { Coexistence of man and reserve of biosphere. }\end{array}$ \\
& $\begin{array}{l}\text { Cultural landscape created by diverse ethnic composition of } \\
\text { population. }\end{array}$ \\
& $\begin{array}{l}\text { Centuries long cultural-social and economic unity crossing over } \\
\text { national borders. }\end{array}$ \\
& Rich settlement architectural traditions related to the land use. \\
\hline Number of settlements & $\begin{array}{l}12 \text { in Austria } \\
10 \text { in Hungary }\end{array}$ \\
\hline Number of population & $48,142(13,402$ in Hungary, 34,740 in Austria) \\
\hline Area & 65,753 ha (6,372 ha Buffer Zone) \\
\hline
\end{tabular}

The goal of our study was to explore both the currently existing and potential newly developing regional connections on different scales between the settlements. Our objective was to highlight the major transformations caused by the appearing and disappearing borders in the relations and changing roles and functions of small towns.

In our research, we cover the following questions:

- What is the role of borders in the changing network within the World Heritage Site?

- What is the current settlement network? Is there a distribution of functions between neighbouring areas and settlements? Are they competitive or complementary?

- What is the role of cultural and natural values in the network?

- Could the recently developed settlement roles and connections form the base of a future ecoregion which includes the World Heritage Area?

\section{Theoretical background based on international literature}

\section{The definition of a small town}

Even the definition of a town is a difficult task because, as a complex network of social, economic and environmental systems with further differences in spatial organisation, a town has been described and defined in many different ways by representatives of various disciplines, stressing different aspects. Thus, there is no single definition of a small town, and therefore we deemed it necessary to create a peculiar, unique definition for the settlements in our research area.

An important aspect in the definitions for towns may be their legal status, their administrative classification. Looking at the specific settlements however, we find that the town status and the functions of a settlement often differ and their administrative status has been changed in the course of centuries. Population is the most often used criterion for a town ${ }^{2}$, but the economic role, the services and the presence of a central role is also important. According to the morphological definition of the ESPON on the road research series, the population density of a small town is above 300 inhabitants per $\mathrm{km}^{2}$, and their population is between 5,000 and 50,000 . They also added a further category of "very small towns", for populations below 5,000. According to the current position of geographical science, towns are distinguished places for exchange, contact and "meeting", and is a product of the spatial division of labour. (Beluszky-

\footnotetext{
2 In Hungary, settlements are normally considered a town if their population exceeds 10,000. However, smaller settlements may also gain a town status on an individual basis, by the roles they fulfill. This is regulated by government regulation 321/2012. (XI. 16.) on the territorial organisation procedure. In Austria, the threshold is 20,000 inhabitants, although smaller settlements may also gain a town status, again on an individual basis (BundesVerfassungsgesetz). There are also featured settlements, based on their historic past, which may have "town communities" (Stadtgemeinde) or "market communities" (Marktgemeinde) as their status (Gemeindestatus), albeit not for administrative purposes.
} 
Tímár, 2003) (Figure 2). "Meeting" is also a central attribute in urbanist Jan Gehl's popular book Cities for people (Gehl, 2010). In our research, the historic roles of the settlements have a great significance in the preservation of cultural heritage; whilst regarding their current roles, their central role - their role in meetings - is very important from the aspect of development.

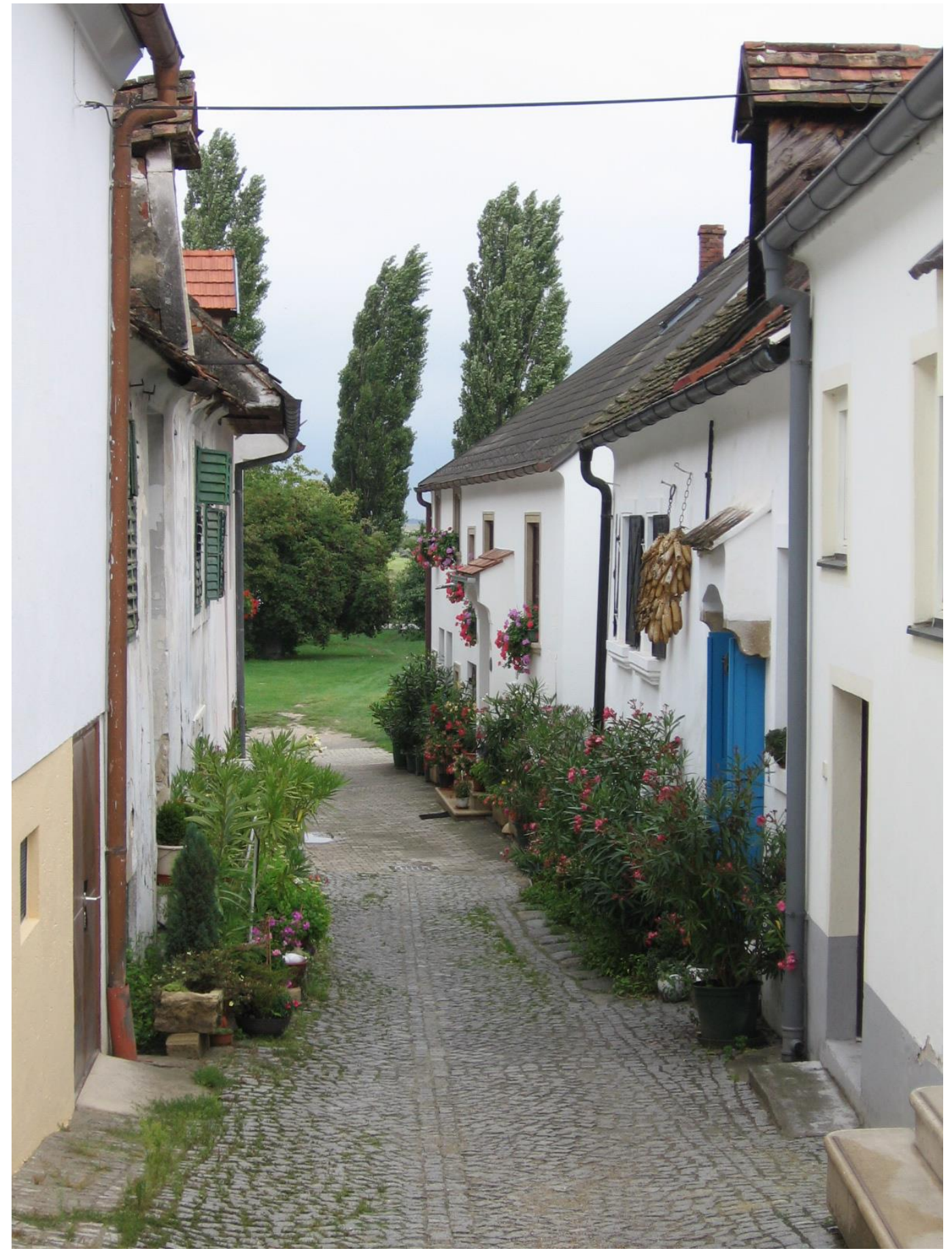

Fig 2. Meeting point of cultures: the small town (Photo by Edina Dancsokné Fóris).

\section{Small towns and spatial development / regional policies}

The European Spatial Development Perspective (ESDP), adopted by the informal meeting of ministers responsible for spatial planning, gives guidelines for EU member states, regions and authorities. This guidance document mentions the goal of polycentric development among the most important objectives for the territory of the EU for the first time. The term of polycentricity has different aspects: morphology and relations. From the point of view of our study, we highlight polycentricity in relations when two or more smaller cities have functions that 
complement each other, and they can offer the range of services as a large city though high level of cooperation.

In many of its regional policy, the EU has already urged the cooperation and joint planning of settlements and nearby regions. The aim and objectives of the 2007 Territorial Agenda of the EU are: Emphasis on strengthening territorial cohesion and presents territorial priorities for the development of the EU, two of which directly concern urban regions and cities:

(1) Strengthening polycentric development and innovation through networking of city-regions and cities;

(2) New forms of partnership and territorial governance. (EU Territorial agenda, 2007)

The 2011 Territorial Agenda brought about only slight changes in this.

Understands urban areas as particularly important regions to focus on and refers directly and indirectly to urban issues in the following territorial priorities:

(1) promoting polycentric and balanced territorial development;

(2) encouraging integrated development in cities, rural and specific regions;

(3) improving territorial connectivity for individuals, communities and enterprises;

(4) managing and connecting ecological, landscape and cultural values of regions.

For our researches, points (2), (3) and (4) are the most important, as the application of these principles can also be the basis for the development of small towns within our research area.

Rural areas, other than those that were purely subsistence-based, were always dependent on cities for their market for agricultural produce, but, with the shifts in the knowledge economy, that interdependence has become much deeper, also facilitated by greater access to both physical and virtual means of communication. The nature of these interactions and deepening of relationships may be seen as increasingly of a partnership nature, where flows are two-way and a variety of governance systems have evolved to manage the relationships (IPOL 2014). Proximity is important to the nature of urban-rural links and relationships, and rural areas close to cities tend to have stronger patterns of interaction, with a reduction of their rural character.

Are small town centres of attraction to their hinterlands? What kinds of interactions or linkages exist between small towns and their hinterlands? Many studies have emphasised the promotion of small towns. They also note that the ability of small towns to play any meaningful role in regional development and rural urban interactions depends on functional local government systems with adequate resources and authority. An emerging view is that each small town and its hinterland (region) is unique and therefore cannot be subjected to standardised theories and concepts. As such, each small town needs to be examined based on its own regional context and peculiarities (Czerny et al. 1997, Owusu 2005).

\section{Ecoregion}

What is an ecoregion? Biodiversity is not spread evenly across the Earth but follows complex patterns determined by climate, geology and the evolutionary history of the planet. These patterns are called "ecoregions". WWF defines an ecoregion as a "large unit of land or water containing a geographically distinct assemblage of species, natural communities, and environmental condition". The boundaries of an ecoregion are not fixed and sharp, but rather encompass an area within which important ecological and evolutionary processes most strongly interact (wwf.panda.org/about_our_earth/ecoregions/about/what_is_an_ecoregion/). However, this definition does not take the social and economic network into account for designation purposes.

Ecoregions should be seen as regions that could be used for various purposes to perform the aggregation of similar terrestrial and aquatic ecosystems in their scope (Milenković 2012). So the regions are to be areas within which biotic and abiotic capacities and potentials are similar. An ecoregion is an ecologically and geographically defined region covering a relatively large area of land or water, and includes characteristic, geographically separate groups of natural communities and species (McMahon et al. 2001). The above-mentioned characteristics 
include geology, physiography, vegetation, climate, hydrology, terrestrial and aquatic fauna and soil - and as well as to a greater acceptance that humans are an important biological component (Omernik 2004).

Regionalism, at the time of global economy and integration processes that are conditioned by it, becomes an unavoidable factor in the sustainable development of countries and wider regions. Ecoregions are an opportunity to bring people of different cultures and countries together around a common interest, to improve their economic and social status, and to maintain their living space and environment in the whole (Milenković 2012).

The basic meaning and purpose of an ecoregionalisational approach is to create a useful spatial framework for comparable assessments in environmental and natural resource management (Milenković 2012). The intention is that this framework will foster an ecological understanding of the landscape. The planning framework also is intended to provide the basis for coordination and collaboration in the design and implementation of ecosystem research, assessment and management (McMahon et al. 2001).

If we are leaving behind the principle of regionalization at the level of political and national boundaries we can focus primarily on economic and sustainable ecological development. This creates a unique space comprising primarily cross-border areas of neighboring states, which often differ in terms of development from the central parts of the country (Milenković 2012).

Tourism as an interdisciplinary economic and social activity can connect all the economic factors of a region, and thus strengthen cross-border geographical areas. The international dimension and that travel destinations are becoming an important factor of national and regional connectivity, emphasise the need for a special type of regionalisation. With the introduction of standards for sustainable tourism development, which should provide long-term conservation and protection of natural, social and cultural resources as basic elements of existence and development, the principles of ecoregionalism become an indispensable factor in planning and merging at all places where natural resources form the basis of economic development (Milenković 2012).

\section{Transboundary protected areas}

Recently, the number of researches of transboundary protected areas (TBPA) is increasing. There are more than 3,000 TBPAs around the world (McCallum et al., 2015). In Europe, mostly the elements of the Natura 2000 network provide the contiguity of natural habitats across the borders, but some biosphere reserves are also TBPAs (Trillo-Santamaría \& Paül, 2016). Occasionally, like in Austria, a pattern analysis reveals that the transboundary contiguity is greater than within the state borders (Opermanis et al. 2013, Busch 2008). The connectivity of the areas strongly correlates with their administration. The study by Opermanis et al. wishes to highlight the importance of decentralisation in the control of conservation areas. A 2015 research of McCallum et al. makes a similar point, and also shows that over a quarter of the protected areas they examined do not communicate with international authorities.

A high connectivity of TBPAs is important for the free movement of species, but invasive species may also spread more easily. In addition, illegal border crossing may also become easier, but in general TBPAs have a positive effect on biodiversity (McCallum et al. 2013).

\section{Methodology}

In our research, we have examined the regional and national connectivity and roles of the settlements in Fertö/Neusiedlersee Cultural Landscape World Heritage Site. We defined the most important nodes of settlement network and highlighted the small towns as potential nodes. We explored the characteristics and type of relations of the settlements concerned. We compared the settlements in the cultural landscape with other settlements in a similar situation (in a cross-border location and being rich both in natural and in cultural historic values).

In our landscape history research, we compared the development potentials in the pre-border (before World War I) and the following periods. We present the landscape conditions according to the world heritage nomination documents. We compared the changing role and functions of 
tourism in the cross-border regions. We draw general and specific conclusions in relation to the nature of transformations and development possibilities of the regions analysed.

\section{Methodology of the historic review}

We applied the practical steps used in landscape history researches, in which we examined the changes in the landscape and in the settlements by studying historic descriptions and maps and by a site survey. We also looked at the changes of roles of the small towns in each era. In the historic review of the region, we identified four distinct periods:

- Undisturbed development up till World War I: in this period, the area and its settlements showed an organic growth and cooperation. The earlier tenure centres evolved into small towns, which distributed the tasks amongst each other.

- Administrative borders between the two World Wars: the border change after World War I impacted the earlier processes, although the roles of the settlements did not change at that time yet.

- 1945 - 1990, closed borders: the border closure after World War II fundamentally changed the settlements and the entire subregion. The former regional centres had lost their roles and become marginal. New networks and centres started to form, mainly on the Austrian side.

- 1990, reintegration: after the end of communism in Hungary, the situation of the region changed: its Western location, its proximity to the Austrian border provided great development opportunities for the settlements on the Hungarian side. The easier crossing of the borders has brought the revival of the former centuries-long connections.

The historical review, the definition of periods was important during our research mainly for the role definitions of the region and especially of the small towns, as the roles developed over the centuries determine the current situation of the settlements, and the possibilities for their potential development as well.

\section{Conditions for becoming an ecoregion}

Ecoregions are ecological rather than political or administrative regions. Ecoregions are areas of similarity regarding patterns in the mosaic of biotic, abiotic, aquatic, and terrestrial ecosystem components, with humans being considered part of the biota. Although ecoregions are helpful for many specific purposes, such as developing regional nutrient criteria and biological criteria for streams, they cannot be expected to correspond perfectly to patterns in any one characteristic. Ecoregion boundaries are areas, rather than lines, where the predominant characteristics of one region meet the predominant characteristics of another (Omernik 2004).

Ecoregions have to fulfill a lot of different criteria: natural and social conditions alike have to be met for a region to become an ecoregion. The development of an ecoregion has no single, universally accepted criteria system. Based on the processed sources, we have defined a system which fits the currently existing ecoregions and could form the basis for the development of a future ecoregion. The conditions that should be considered during the development are the following:

Natural conditions:

- consistent climatic, geologic, geographic and hydrographic attributes;

- high biodiversity, diverse flora and fauna;

- a high rate of near-natural or protected areas;

- peculiar land use aligning to the landscape attributes.

Social conditions:

- cooperating communities (both within and across settlements);

- a commitment to environmentalism;

- social participation;

- a project-oriented attitude (having economic and environmental sustainability in mind), 
- impartiality, political neutrality.

- preservation of built, natural and cultural values.

\section{Examination aspects for the roles of small towns}

In our research area, we find very small towns according to the definitions of ESPON, and an important aspect in their lives - in fact, one of the reasons for their inclusion on the World Heritage List - is that cultures are meeting in them. Around the region, there are many small towns with central role; however, agreeing with Beluszky's another conclusion that the town character of the settlements does not necessarily imply the appearance of pronounced agglomerations (thus, the central role is not a criterion for being a town). World Heritage Site settlements - with the single exception of Neusiedl am See - all have a population lower than 5,000 . As we have mentioned before, the set of very small towns cannot be defined easily with a single rule, therefore an original definition had to be created.

We have the biggest chances for finding meetings in central locations, thus we classified the settlements by their significance in meetings, in order to determine which of them are small towns. Meetings, regarding the settlements, were defined by three central characteristics:

- administrative;

- tourism;

- cultural.

An administrative centre is a settlement with a central administrative or conservational institute. This condition is also a generic characteristic for urbanity, and is important for the planning and managing the execution of spatial development as well. Highlighting the tourism central role is reasoned by the special natural values of the region, beyond the meeting functions. Tourists are attracted to the region by its richness in natural values, which is an economic advantage, but it is also a threat to the sustainability of these values. Spatial development should therefore pay special attention to tourism development. Let us also not it already here that small towns functioning as tourism centres have a special responsibility in protecting natural values. This is why we found it important to list tourism amongst the central characteristics in the definition of a small town.

Furthermore, the intention of preserving the cultural heritage and the diverse development paths of the settlements on the two sides of the border required us to regard any settlement currently or historically possessing a town status as a small town in our research. In the final definition however, we also considered the current roles of the settlements. Thus, a settlement playing an important role in meetings - that is, an important administrative, cultural and tourism centre in the region - was also classified as a small town (Nagycenk). However, a former market town, having no central function whatsoever today, thus not being a location for meetings, was excluded (Oggau).

We also took the regional roles into account, based on the regional development plans (LEP). We consider the settlements meeting these conditions as small towns, listed in Table 3 in bold.

\section{Empirical knowledge}

Here we present our historical results of research, role and functions of the settlements, characteristics of settlement network and tourism potentials.

\section{Experiences and results of the landscape and settlement history research}

The organic development of the region had been broken by the new state borders defined by the Treaty of Trianon, a peace agreement after World War I. The German-inhabited parts of Western Hungary had been awarded to Austria - including almost half the area of Sopron county: the entire territories of the districts of Nagymarton, Kismarton and Felsöpulya, and partly also the district of Sopron. On a later local referendum (on 14 December 1921), 72.75 per cent of the population of Sopron and its agglomeration voted for staying with Hungary. In reference to the result of the referendum, the inscription on the sculptural group above the city gate (by 
Zsigmond Kisfaludi Strobl) reads "Civitas Fidelissima", "The most loyal city". This is how the peculiar border shape, the "Sopron bag", came to existence. Sopron turned into a periphery, accessible only from the east (FERTÖ TÁJ 2003).

Without Sopron, the Austrian state of Burgenland remained without a capital. A quick decision was made to select Eisenstadt as the capital, a noble family seat which used to be of much less significance until that time (burgenland.at).

After World War II, Györ-Moson county was created in 1945 by the merger of former county Györ and the once westernmost county Moson (as the latter had been split between three countries: Hungary, Slovakia and Austria).

Being a border zone, the strict administrative measures limited the development of Sopron and its region (and also the development of the nearby city of Mosonmagyaróvár) in the 1950s, whilst the industry of Györ could start to develop. Then in the 1960s, as part of Kádár's "consolidation of socialism", the more than $10 \mathrm{~km}$ wide border zone was dismantled, and the development of Sopron could finally start (FERTÖ TÁJ 2003). Most of the smaller settlements of the Lake Fertő region started to decline following a flawed spatial development decision (the 1971 National Spatial Development Concept). For these reasons, Lake didn't develop potential for tourism.

The next important change in the administrative structure was the abolition of districts in 1983, following the 1971 abolition of district councils. The independence of municipal councils strengthened, and the districts had been replaced by suburban zones. Kapuvár and Csorna became towns (in 1969 and 1971, respectively). After the abolition of the district system, Sopron was the centre of public supplies on the intermediate level for about 40 settlements, in a very similar way to its former district. The settlements were classified into two groups, and "large villages" were formed. All the towns become uniformly become parts of the administration of the county.

The end of communism in 1990 brought significant changes in the administration, but not in the territories. The establishment of a truly municipality-based public administration had started, and municipalities were formed on local and county levels. Fertőszentmiklós became a town in 2008.

In the region of Fertö, joint municipal offices were created, in line with the Act CLXXXIX of 2011 on the local municipalities of Hungary. The World Heritage Site is administered by four of such joint municipal offices. The periods and main events of landscape history are summarised in Table 2.

Tab 2. Periods of landscape history.

\begin{tabular}{|l|l|}
\hline $\begin{array}{l}\text { Undisturbed } \\
\text { development up } \\
\text { till World War I. }\end{array}$ & $\begin{array}{l}\text { The entire region belongs to one country. } \\
\text { Agricultural use is dominant. Settlement relations are intact. } \\
\text { The central town of the region is Sopron. }\end{array}$ \\
\hline $\begin{array}{l}\text { Administrative } \\
\text { borders } \\
\text { between the } \\
\text { two world wars }\end{array}$ & $\begin{array}{l}\text { A border divides the region. Different development potentials are } \\
\text { characteristic for the divided parts. } \\
\text { The land use system has not changed. In addition to Sopron as a natural } \\
\text { town with centre functions, Eisenstadt, the new capital of Burgenland also } \\
\text { started to develop as an administrative centre. }\end{array}$ \\
\hline $\begin{array}{l}1945-1990: \\
\text { closed borders }\end{array}$ & $\begin{array}{l}\text { The Iron Curtain separates the region. The Austrian part develops further, } \\
\text { the Hungarian region becomes a stagnating periphery. } \\
\text { In Austria, tourism and agriculture, whilst in Hungary, nature protection } \\
\text { and agriculture dominate. Sopron, after a setback, starts to slowly } \\
\text { develop with the loosening dictatorship. Eisenstadt is gets stronger. }\end{array}$ \\
\hline $\begin{array}{l}\text { 1990- } \\
\text { reintegration }\end{array}$ & $\begin{array}{l}\text { Reborn relations between the settlements. Sopron is again the natural } \\
\text { centre also of its Austrian agglomeration, but only one of its satellite } \\
\text { towns has become part of the World Heritage Site, Sopron itself has not. }\end{array}$ \\
\hline
\end{tabular}


On the Austrian side, the least developed state of the country, Burgenland was established. The development of agriculture, especially of viniculture however has strengthened it economically. In addition, there was a short period of mass tourism interest by the citizenry of Vienna, who liked to spend a weekend or only a day near Lake Fertö. Nonetheless, Burgenland remained the eastern periphery of Western Europe almost until the fall of the Iron Curtain.

The town status of Rust (BFg) has its roots in the Middle Ages. Despite its small size, it is still a town today, and, from the aspect of tourism, it is the most frequently visited settlement around the lake. There are also some special settlements due to their historic past - these may have the status (Gemeindestatus) of either "town communities" (Stadtgemeinde) or "market communities" (Marktgemeinde). This does not mean a town status from an administrative aspect though. (These are noted in Table 3 and Figure 3.) The Austrian side did not experience such a decline as the Hungarian settlements, thus Austrian settlements have a greater population on average than the Hungarian villages and small towns.

Nature conservation and efforts for sustainable economic development in rural areas gave birth to nature parks. There is a long tradition of these "Naturparks" in Austria. The NeusiedlerseeLeithagebirge Naturpark, partially overlapping with the World Heritage Site (the settlements of Donnerskirchen, Purbach, Breitenbrunn and Jois form the intersection), is situated in Burgenland. The inhabitants of the nature park consider the meeting of mountains, plains and the lake, of man and nature to be their biggest value. Winden also belongs to the Naturpark, but it is not part of the World Heritage Site (neusiedlersee-leithagebirge.at).

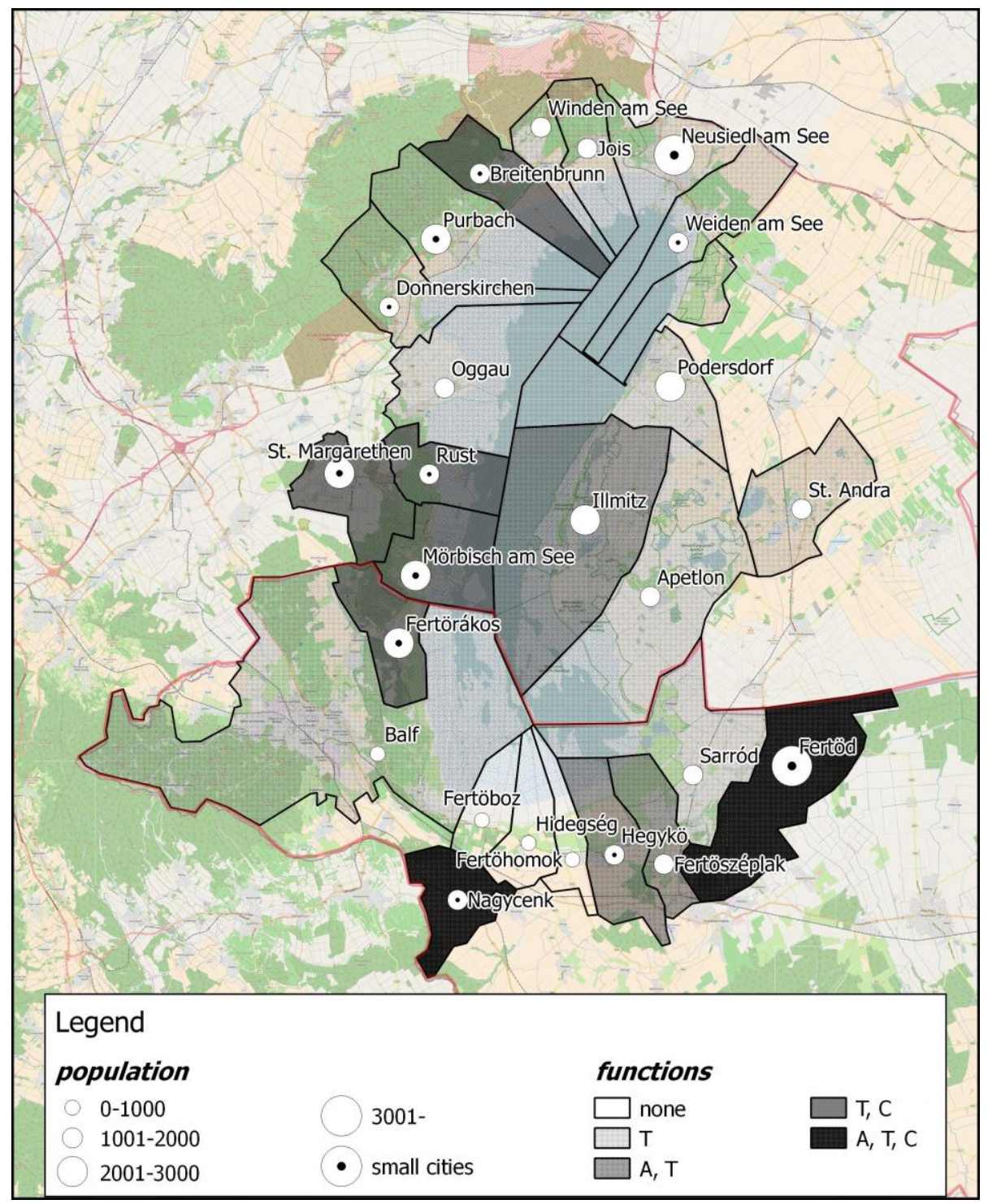

Fig 3. The role of the settlements (created by Klaudia Máté, using OpenStreetMap standard map and data from Table 3). 
Tab 3. The role of the settlements involved.

\begin{tabular}{|c|c|c|c|c|}
\hline $\begin{array}{l}\text { Name of } \\
\text { settlement } \\
\text { (settlements we } \\
\text { classified as small } \\
\text { towns are in bold) }\end{array}$ & $\begin{array}{l}\text { Former legal status } \\
\quad \text { (before 1945) }\end{array}$ & Current legal status & $\begin{array}{l}\text { Current } \\
\text { population } \\
\text { and } \\
\text { population } \\
\text { density }\end{array}$ & $\begin{array}{l}\text { Role in "meetings" } \\
\text { (centre functions: } \mathbf{A}-\text { administrative centre, } \mathbf{T}-\text { tourism centre, } \mathbf{C}-\text { cultural centre) }\end{array}$ \\
\hline Fertörákos & medieval market town & community & $\begin{array}{l}2208 / \\
100.8\end{array}$ & $\begin{array}{l}\text { T, C: dock, marina, quarry and theatre open to visitors, several thousand years old World } \\
\text { Heritage monuments, Pan-European Picnic Memorial Park, fostering German minority } \\
\text { culture }\end{array}$ \\
\hline Balf & community & a district of Sopron city & & T: spa of international significance and fame, bicycle path \\
\hline Fertőboz & community & community & $294 / 21.6$ & World Heritage monument, rest area at bicycle path \\
\hline Hidegség & community & community & $361 / 21.4$ & rest area at bicycle path \\
\hline Fertőhomokrest & community & community & $605 / 48.0$ & rest area at bicycle path \\
\hline Nagycenk & community & community & $1,887 / 97.0$ & A, T, C: joint municipal office, equestrian centre, World Heritage monument \\
\hline Hegykő & $\begin{array}{l}\text { market town in the } 18^{\text {th }} \\
\text { century }\end{array}$ & community & $1,433 / 53.4$ & $\begin{array}{l}\text { A, T: joint municipal office, spa of regional importance and of international fame, rest area at } \\
\text { bicycle path }\end{array}$ \\
\hline Fertőszéplak & community & community & $1,256 / 57.7$ & $\begin{array}{l}\text { A, T: office of Fertö-táj World Heritage Hungarian Council Association joint municipal office, } \\
\text { rest area at bicycle path }\end{array}$ \\
\hline Sarród & community & community & $1,099 / 27.4$ & T: national park directorate \\
\hline Fertőd & community & city & $3,261 / 67.2$ & $\begin{array}{l}\text { A, T, C: World Heritage monuments, a music festival centre of regional importance, } \\
\text { headquarters of Fertö-táj World Heritage Hungarian Council Association, county community } \\
\text { centre, fostering German minority culture }\end{array}$ \\
\hline Apetlon & community & community (Marktgemeinde) & $1,784 / 22$ & T: bicycle path, horse-riding tour path, part of running park, spa \\
\hline Illmitz & community & community (Marktgemeinde) & $2,477 / 27$ & A, T: national park directorate, dock, part of running park, marina \\
\hline St. Andrä & community & community (Marktgemeinde) & $1,359 / 43$ & T: Zicksee swimming lake, running park section \\
\hline Podersdorf & community & community (Marktgemeinde) & $2,078 / 50$ & T: bicycle path, dock, running park section \\
\hline Weiden am See & $\begin{array}{l}\text { having market rights in } \\
\text { the } 16^{\text {th }} \text { century }\end{array}$ & community (Marktgemeinde) & $1,922 / 70$ & T: bicycle path, sailing boat dock \\
\hline Neusiedl am See & $\begin{array}{l}\text { having market rights in } \\
\text { the } 16^{\text {th }} \text { century }\end{array}$ & community (Stadtgemeinde) & $7,005 / 105$ & T: bicycle path, medieval castle \\
\hline Jois & community & community (Marktgemeinde) & $1,425 / 59$ & T: part of nature park, bicycle path \\
\hline Winden am See & community & community (Gemeinde) & $1,250 / 92$ & T: Amber Road, part of nature park, bicycle path \\
\hline Breitenbrunn & $\begin{array}{l}\text { having market rights in } \\
\text { the } 17^{\text {th }} \text { century }\end{array}$ & community (Marktgemeinde) & $1,910 / 74$ & $\begin{array}{l}\text { T, C: Amber Road, } 17^{\text {th }} \text { century fortress, sculptural centre - Breitenbrunn stone; part of } \\
\text { Welterbe-Naturpark Neusiedler See Leithagebirge, bicycle path station, dock }\end{array}$ \\
\hline Purbach & $\begin{array}{l}\text { having market rights in } \\
\text { the } 17^{\text {th }} \text { century }\end{array}$ & community (Stadtgemeinde) & $2,715 / 59$ & $\begin{array}{l}\text { T: Roman fortress, Amber Road, } 17^{\text {th }} \text { century fortress; part and centre of Welterbe-Naturpark } \\
\text { Neusiedler See Leithagebirge; bicycle path station }\end{array}$ \\
\hline Donnerskirchen & $\begin{array}{l}\text { having market rights in } \\
\text { the } 17^{\text {th }} \text { century }\end{array}$ & community (Marktgemeinde) & $1,739 / 48$ & $\begin{array}{l}\text { T: Amber Road, medieval fortress, part of Welterbe-Naturpark Neusiedler See Leithagebirge, } \\
\text { bicycle path station }\end{array}$ \\
\hline Oggau & community & community (Marktgemeinde) & $1,788 / 34$ & T: bicycle path station \\
\hline St. Margarethen & $\begin{array}{l}\text { having market rights in } \\
\text { the Middle Ages }\end{array}$ & community (Marktgemeinde) & $2,727 / 103$ & $\begin{array}{l}\text { T, C: Amber Road; bicycle path station; opera festival in Roman quarry, Familypark } \\
\text { Neusiedlersee }\end{array}$ \\
\hline Rust & $\begin{array}{l}\text { medieval market place, } \\
\text { later a "royal free town" }\end{array}$ & city (Freistadt) & $1,896 / 96$ & $\begin{array}{l}\text { T, C: member of Kleine Historische Städte in Österreich, Turkish fortress, headquarters of } \\
\text { Austrian Wine Academy, bicycle path station, rowing boat centre, beach, dock }\end{array}$ \\
\hline Mörbisch am See & medieval market town & community (Gemeinde) & $2,261 / 79$ & $\begin{array}{l}\text { T,C: bicycle path station, dock, water stage, operetta festival, pedestrian and bicycle border } \\
\text { crossing }\end{array}$ \\
\hline
\end{tabular}




\section{Regional connections}

The Regional Development Plan of Burgenland 2011 (Landesentwicklungsplan / LEP 2011) highlights the importance of cooperation, and intends to strengthen cross-border relations which are not very strong currently. LEP emphasises one of the future development scenarios for the region with the slogan: "Growing together - Living better together" (Figure 4).

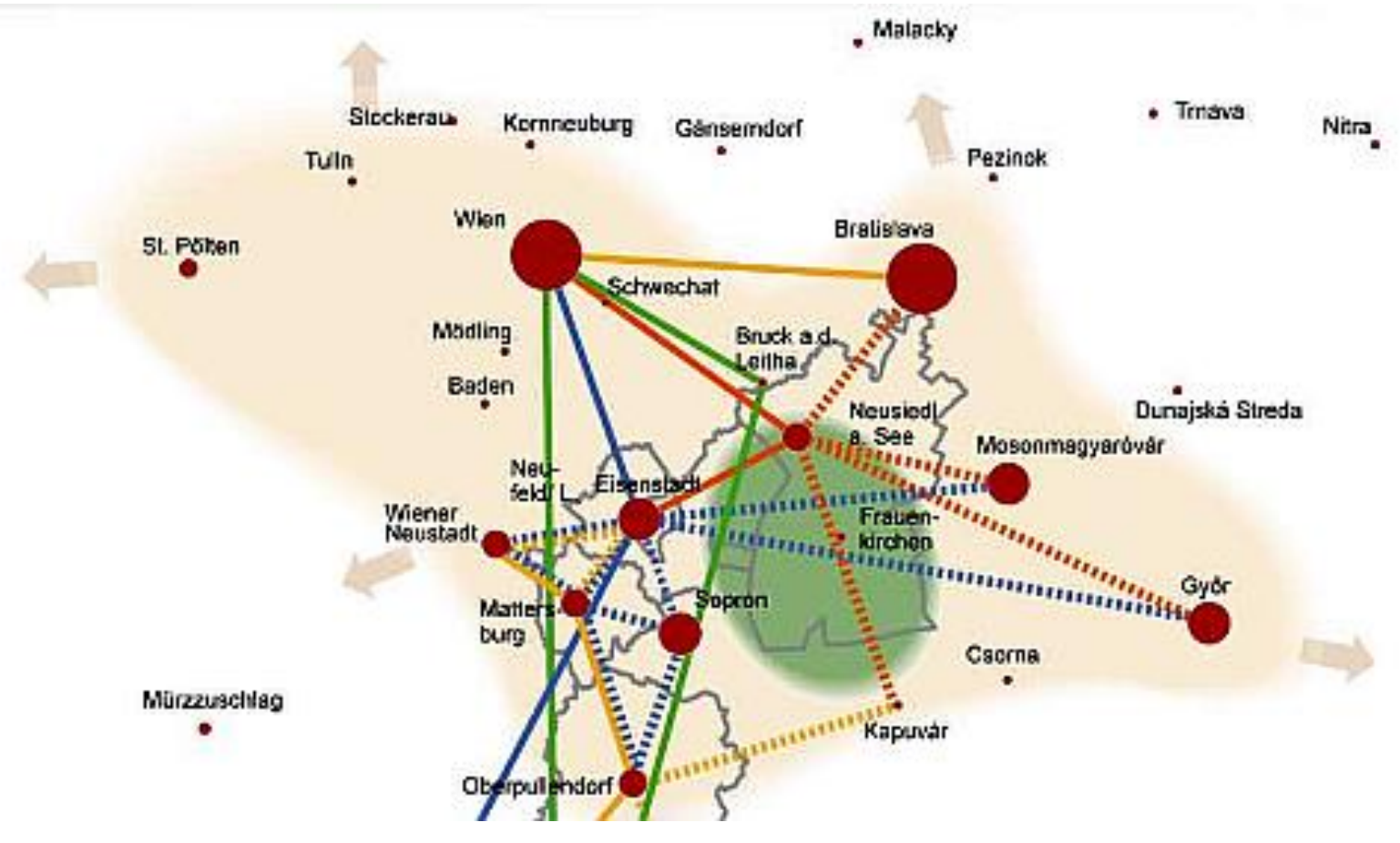

Relations

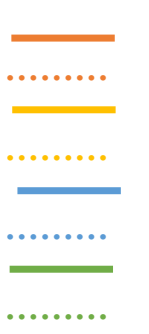

Existing \& Planned

Existing,

Planned

Existing,

Planned

Existing,

Planned

Existing,

Planned

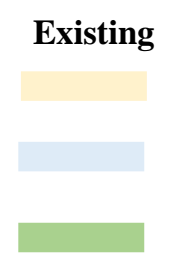

Networks

Mid-Northern Network

Mid-Southern Network

Cross-border nature protection co-operation

Source:

Fig 4. Networks of cooperation: "Growing together - Living better together" from the Regional Development Plan of Burgenland.

Developing the management plans requires a deep cooperation from both sides of the border, also on a regional level. The management plans are being made as a joint effort, after proper consultations, though the countries involved also make arrangements individually for the protection of the values.

There are many cities near Fertö/Neusiedlersee (Győr, Bratislava, Vienna, Wiener Neustadt, Eisenstadt, Bruck an der Leitha, Sopron, Köszeg, Szombathely, Kapuvár), but they do not belong to the World Heritage Site. The Austrian part of Lake Ferto is in the second circle of Vienna's functional urban area. On the local level, the most important nodes of the settlement network are Eisenstadt (Austria) and Sopron (Hungary). So the cities outside the World Heritage Site have exceptionally great influence on the life of the settlements around the lake. All of the settlements on the Hungarian side belong to the Leader rural development group AlpokaljaFertö-táj, while the settlements in Austria are members of Nordburgenland Plus Local Action Group. The long-term sustainable development depends on the extension of the current cooperation. 


\section{Natural heritage in cross-border context}

To be included on the World Heritage List, a nominated area must meet at least one selection criteria set by UNESCO (whc.unesco.org/en/criteria/). Fertö/Neusiedlersee Cultural Landscape, the research area in this study, meets criterion, as it is a meeting point of cultures which are different for many thousands of years, thus it is an outstanding example of their coexistence, and also of a harmonious relationship between man and its environment. According to the natural-cultural classification, it is part of the cultural World Heritage, although it could also fit into the category of natural World Heritage just as well, considering that on an international level, it is a biosphere reserve since 1979 (Lake Fertő Biosphere Reserve), a Ramsar area, a part of the Natura 2000 network, and also almost every possible nature conservational and other protections apply to it on a national level. Lake Fertő, as a natural element and tourist attraction, is an unquestionable link in this landscape of high cultural value. According to Timothy (1995), the location of tourist areas compared to the political borders predetermines the interest in an area. In the case of Lake Fertö, we can calculate with the most favourable potentials, as the contiguous natural value transcends the state border, thus the separating, fragmenting role of the latter diminishes. Therefore, cross-border World Heritage Sites may become excellent international tourism destinations provided there is an appropriate natural, social and cultural environment on both sides of the border (Eriksson 1979).

\section{Conclusion and discussion}

The development of Fertö/Neusiedlersee World Heritage Site is a good example for the cooperation of the settlements. Small towns do not deprive resources from the nearby villages, but they cooperate whilst leaving the possibility of a complete life for them, resulting in a win-win situation. (Despite the fact that in both countries, the most important decisions are not made on a local level. In Austria, the decision-making is on a regional level, and in Hungary, Fertö-táj World Heritage Hungarian Council operates under ministerial supervision.)

The connections between the settlements in the region are diverse, but the presence of the state border still has a noticeable effect. Small towns could have a key role in developing a close connection network in the area around the lake - just like how they already do in the two countries separately. It would be important to strengthen the cross-border connections to express cohesion in the landscape, to further develop the cultural landscape as part of the World Heritage.

\section{Regional and settlement connections}

Fertö/Neusiedlersee Cultural Landscape has almost better transport connections towards Austria than towards the centre of Hungary - this demonstrates the peculiar situation of the region. The World Heritage Site is located on the edge of Austria, in the peripheral region of the Vienna-Györ-Bratislava "Golden Triangle", in the southern "pillar" of the Centrope region. Fertö/Neusiedlersee Cultural Landscape is the green heart of the Vienna-Bratislava-Györ European metropolitan region, and its development was highlighted in the Jordes+ programme (Joint Regional Development Strategy for the Vienna-Bratislava-Györ region), which itself is part of the Interreg programme. The aim of Jordes+ was to provide an opportunity for joint regional strategic planning and initiating projects for the involved Austrian states, the region of Bratislava, and Györ-Moson-Sopron county, and within that, the city of Györ.

The second most important public road of Győr-Moson-Sopron county, the M85 motorway crosses through the settlements around Fertö. The area is connected to the national road network via Road 85 and Road 84 . Road 85 is connected to the M1 motorway, providing a road link to the country seat and to the capital, increasing the importance of the road. Border crossings towards Austria are between Sopron and Klingenbach (Kelenpatak), accessible via Road 84; between Kópháza and Deutschkreutz (Sopronkeresztúr), via Road 861; and between Fertöd and Pamhagen (Pomogy). The Györ-Sopron railway section is part of the national main line network.

In the World Heritage Sites, our observation was that belonging to a World Heritage forced the joint planning in the cross-border areas. Every management plan had the following goals: 
- preservation of the World Heritage;

- protection of natural and cultural values;

- development of tourism in line with the goals above.

However, these goals cannot be reached simply on a management planning level. The planning process touches problems which can be solved only by a joint economic, social and environmental planning in the region. Around Lake Fertö, despite the fact that the most important decisions are not made on a local level, there are already signs of cooperation between the small towns. In Austria, the decision-making is on a regional level, and in Hungary, Fertő-táj World Heritage Hungarian Council operates under ministerial supervision. Cities in the wider region with spatial organisational power: Eisenstadt and Sopron, as well as Vienna and Györ are located outside the World Heritage Site.

The area of Lake Fertő appears as a green patch in the regional connection network. Around the lake, Neusiedl am See is the only significant settlement which has a central role. A closer cooperation of these region organising nodes would be necessary. Having polycentricity in mind regarding regional development, strengthening the connections between small towns could result in such an independent network cooperation of settlements, which could provide the conditions for the development of the entire region. According to our analyses, the following settlements are small towns in the region: Fertőrákos, Nagycenk, Hegykő, Fertőd, IIImitz, St. Andrä, Podersdorf, Weiden am See, Neusiedl am See, Breitenbrunn, Purbach, Donnerskirchen, St. Margarethen, Rust and Mörbisch am See.

Sopron plays a role in the region due to its proximity, and it also has a community organising power (which reaches across the border). These, together with its historic background, would enable the city to become a regional centre, but only through cooperation with Eisenstadt.

The other settlements - regardless of their current classification - could have a significant role in developing a connection network. This region is not an agglomeration: it is a network of settlements of roughly equal rank, which collectively are able to fulfill all the required functions for the local inhabitants and tourists alike, also protecting the heritage.

We examined more thoroughly the selection criteria for small towns which form the basis of network development in Fertö/Neusiedlersee Cultural Landscape, and we compared them to the criteria in the Regional Development Plan of Burgenland. We found that the criteria we applied (having an historic town character and being a current meeting point) define the settlements with centre functions, regardless of their town status. Thus, a small town character or the central role of a settlement can be described by the two criteria we have chosen. These criteria may have a significance in regions which have a low number of cities and great natural values.

It was observed that the management plans relied on

- the joint historic past,

- the joint natural and cultural values, and

- the potential in tourism (also increasing the economic potential in the area) as resources.

In Fertö/Neusiedlersee Cultural Landscape, the diversity formed by the meeting of different cultures was especially important, and in a planning environment aiming at the re-creation of the territorial integrity, the conservation of that diversity is especially challenging. To resolve this, we suggest to form twin town relationships within the region, based on the minority communities of the settlements. Small town municipalities maintaining various educational and cultural institutions could have a key role in securing the coexistence and conservation of minority cultures. Neither the larger cities located farther away, nor the small municipalities lacking the tools can perform this task.

Based on all this, we believe that not only the management plan of the World Heritage Site, but every regional plan and regional programme should be developed jointly, taking the entire cross-border region into consideration. 


\section{The role of landscape integration/unity in the settlement network}

"Landscape means an area as perceived by people, whose character is the result of the action and interaction of natural and / or human factors" (EUROPEAN COUNCIL 2000). Every landscape and region is different. The concept of landscape character provides an opportunity to describe the attributes defining the uniqueness of a landscape. In the case of Fertö/Neusiedlersee Cultural Landscape, the natural environment, the settlements, and the agricultural areas cultivated for many centuries all belong to the landscape character - the most peculiar examples to the latter are the vineyards. The establishment of Fertö/Neusiedlersee World Heritage Site was a great basis for the conservation of the natural heritage, as it means a further level of protection for the area. However, the numerous parallel protections (Natura 2000, Ramsar Area, national park etc.) may also mean an obstacle in the integrated management of the area. In the World Heritage Site management plan, nature conservation and the protection and demonstration of settlement values are of equal importance. But in the longterm tourism developments, it is very important to ensure that the protections are not being seen as limitations but as a basis for development, as the disappearance of values could lead to the loss of the World Heritage. In Fertö/Neusiedlersee World Heritage Site, settlements, and small towns especially have an important role in the conservation and demonstration of values, because the locations of tourism infrastructure and of regional developments and grants are the settlements. Conserving the character of Fertö/Neusiedlersee Cultural Landscape can only be achieved by conserving the characters of the settlements. Urban planning is an appropriate tool, in which only developments in line with the landscape character should be allowed, both on the Austrian and on the Hungarian side.

According to our researches, the challenges in regions which are located in background areas, have special values and face similar problems, may be tackled by adopting the following development suggestions:

- joint regional development based on small towns with a shared history and appropriate meeting points;

- the application of the concept of ecoregion to World Heritage Sites where natural factors are important in the formation and identity of the region;

- landscape character based landscape designation, and the strengthening of landscape identity.

There are many reasons for establishing the ecoregion by extending the World Heritage Site. The most important reason might be an increased economic sustainability, as more diverse natural and social attributes could be the key for economic sustainability in the future. A merger with Írottkő Nature Park on the Hungarian side may also be considered.

\section{Possibilities for the ecoregion}

In the designation of the suggested Lake Fertö Ecoregion, we took the example of the Kaindorf Ecoregion in Austria for its similar attributes. Kaindorf Ecoregion was established in 2007 with the aim of setting an example for other Austrian regions. The goals of the ecoregion are:

- ecologically sustainable farming,

- maximising the use of renewable energy sources,

- maintaining the fertility of the soils,

- developing a carbon-neutral economy and society.

Over almost a decade of operation, the founding municipalities (Dienersdorf, Ebersdorf, Hartl, Hofkirchen, Kaindorf and Tiefenbach) created many joint projects. They connected the settlements with greenways, which support both non-motorised transport and tourism; they developed a methodological handbook promoting topsoil-friendly agriculture, and spreading knowledge on composting. With the participation of the active members of the community, they calculated the carbon footprints of the settlements in the region, and started to shrink them. For its outstandingly successful performance, the ecoregion won the "Best of Green Events Austria Award 2016" (http://www.oekoregion-kaindorf.at/). 
[1] 321/2012. (XI. 16.) Korm. rendelet a területszervezési eljárásról.

[2] 1971 Országos Területfejlesztési Koncepció (1971 National Spatial Development Concept).

[3] Beluszky, P. \& Tímár, L. (2003). Magyarország történeti földrajza. Budapest-Pécs: Dialóg Campus Kiadó.

[4] Bundes-Verfassungsgesetz:

http://www.ris.bka.gv.at/GeltendeFassung.wxe?Abfrage=Bundesnormen\&Gesetzesnummer $=10000138$ (Retrieved: 1 April 2016).

[5] Busch, J. (2008). Gains from configuration: The transboundary protected area as a conservation tool. Ecological Economics 67(3), 394-404. Doi: 10.1016/j.ecolecon.2007.12.012.

[6] Czerny, M., van Lindert, P. \& Verkoren, O. (1997). Small and intermediate towns in Latin American rural and regional Development (pp. 1-14). In Lindert, van P. \& Verkoren, O., eds., Small Towns and Beyond: Rural Transformation and Small Urban Centres in Latin America, Amsterdam: Thela Publishers.

[7] Eriksson, G. A. (1979). Tourism at the Finnish-Swedish-Norwegian borders (pp. 151-162). In Gruber, G., Lamping, H., Lutz, W., Matznetter, J. \& Vorlaufer, K., eds., Tourism and Borders: Proceedings of the Meeting of the IGU Working Group - Geography of Tourism and Recreation Institut für Wirtschafts- und Sozialgeographie der Johann Wolfgang Goethe-Universität, Frankfurt am Main.

[8] Európa Tanács/European council (2000): Európai Táj Egyezmény. (2007. évi CXI. törvény a Firenzében, 2000. október 20-án kelt, az Európai Táj Egyezmény kihirdetéséről).

[9] Fertö-táj Kultúrtáj világörökségi kezelési terve, Stadtland-AVL-Bécs, VÁTI KHT-Budapest, 2003.

[10] Gehl, J. (2010). Cities for people. Washington-Covelo-London: ISLANDPRESS.

[11] Gemeindestatus: http://www.burgenland.at/land-politik-verwaltung/land/bezirke-gemeinden/ (Retrieved: 1 April 2016).

[12] Hamza, C., Frangenheim, A., Charles, D. \& Miller, P. (2014). The role of cities in cohesion policy 2014-2020. Brussel: European Parliament. Doi: 10.2861/6801.

[13] Közép- és Kelet-Európa. Rejtett potenciál a kis- és középvárosokban. European Union, az ESPON 2013 Program keretében futó ESPON on the road projekt, magyar kiadás. http://esponontheroad.eu.

[14] McCallum, W., J., Vasilijevic, M. \& Cuthill, I. (2015). Assessing the benefits of Transboundary Protected Areas: A questionnaire survey in the Americas and the Caribbean. Journal of Environmental Management 149, 245-252. Doi: 10.1016/j.jenvman.2014.10.013.

[15] McMahon, G., Gregonis S. M., Waltman, S. W., Omernik, J. M., Thorson, T. D., Freeouf, J. A., Rorick, A. H. \& Keys, J. E. (2001). Developing a Spatial Framework of Common Ecological Regions for the Conterminous United States. Environmental Management 28(3), 293-316. DOI: $10.1007 / \mathrm{s} 002670010225$.

[16] Milenković, M. (2012). Ecoregionalism - Factor Cross-Border Cooperation and Tourism Development. Procedia - Social and Behavioral Sciences 44, 236-240. Doi: 10.1016/j.sbspro.2012.05.025.

[17] Omernik, J. M. (2004). Perspectives on the Nature and Definition of Ecological Regions. Environmental Management 34(Suppl. 1), S27-S38. DOI: 10.1007/s00267-003-5197-2.

[18] Opermanis, O., MacSharry, B., Evans, D. \& Sipkova, Z. (2013). Is the connectivity of the Natura 2000 network better across internal or external administrative borders? 
Biological Conservation 166, 170-174. Doi: 10.1016/j.biocon.2013.06.019.

[19] Owusu, G. (2005). The role of district capitals in regional development: linking small towns, rural-urban linkages and decentralisation in Ghana. [PhD theses]. Trondheim: Norwegian University of Science and Technology.

[20] Pedersen, A. (2002). Managing Tourism at World Heritage Sites: a Practical Manual for World Heritage Site Managers. Paris, UNESCO World Heritage Centre.

[21] Strategie Raumstruktur Landesentwicklungsplan Burgenland (2011). [Endbericht]. Mecca consulting and Regional Consulting ZT GmbH.

[22] Territorial Agenda of the European Union. Towards a more competitive and sustainable Europe of diverse regions. Agreed on the occasion of the Informal Ministerial Meeting on Urban Development and Territorial Cohesion. Leipzig 24/25 May 2007.

[23] Territorial Agenda of the European Union 2020 (2011). Towards an Inclusive, Smart and Sustainable Europe of Diverse Regions. Agreed at the Informal Ministerial Meeting of Ministers responsible for Spatial Planning and Territorial Development on 19 May 2011. Gödöllö, Hungary.

[24] Trillo-Santamaría, J. M. \& Paül, V. (2016). Transboundary protected areas as ideal tools? Analyzing the Gerês-Xurés transboundary biosphere reserve. Land Use Policy 52, 454463. Doi: 10.1016/j.landusepol.2015.12.019. 